\title{
Analysis of Availability and Usage of Information and Communication Technology (ICT) Resources in the Teaching of Physics in Science Secondary Schools in Kano State
}

\author{
Garba Bala Doguwa, Oluwaniyi Steve Dele
}

\begin{abstract}
The study investigated the analyses of the availability and usage of Information and Communication Technology (ICT) Resources in the teaching of Physics in Science Secondary Schools in Kano state. A descriptive survey design was used for the study in Kano state.Tthe population of the study consisted of all physics teachers drawn from science schools.Since the population is sizeable, there was no sampling. Data was collected using teachers questionnaire tagged: "ICT resources availability in science schools (ICTRASS) and ICT resources usage in science schools (ICTRUSS). The data obtained were analyzed using SPSS version 19.0;mean and standard deviation were used as statistical tools. The result showed that ICT resources are not available in most of the science schools and that most Physics teachers do not utilize even the few available ICT resources in teaching Physics. It was therefore recommended that government and non-governmental organizations should work hard to assist in the supply of ICT resources including internet connectivity for effective teaching and learning of Physics. Finally, massive training should be organized from time to time to make Physics teachers effective in the usage of ICT resources.
\end{abstract}

Index Terms - ICT Resources, Availability, Usage, Physics teachers.

\section{INTRODUCTION}

Information and Communication Technology (ICT) has become a key tool and has a revolutionary impact on how we see the world and how we live. The place of ICT in education and the world, in general,cannot be undermined. Modern-day business is carried out with a fax machine,telephone, computers, and communication networks through the internet. This phenomenon has given birth to the contemporary e-commerce, e-government, e-medicine, e-banking, and e-education among the others. Information and Communication Technology is gradually affecting the nature of learning and production of knowledge and transforming the world in an unexpected way, Richmond (2018). This has facilitated the paradigm shift from the traditional instructional material or traditional pedagogical methods to a modern and innovative technology-based teaching and learning method.

Information and Communication Technology refers to

Garba, Bala Doguwa, Mathematical Sciences Education Programme, National Mathematical Centre, Abuja.

Oluwaniyi, Steve Dele (Ph.D), Mathematical Sciences Education Programme, National Mathematical Centre, Abuja. the process of getting, accessing and dissemination of data for enhanced learning Karanji (2018).It is daily giving rise to new concepts, ideas and making an impact not only in the business/industries but also in the education sector. ICT has simplified education through the application for electronic media, internet etc. According to Husain (2019), the production and introduction of calculators and computers in the education system worldwide have helped in simplifying teaching and learning in schools, thereby promoting national stability and economic survival.However, successful implementation of ICTs requires strategic planning and government support for finance and policy. Improved education is essential to the creation of effective human capitals in any country.The need for ICTs in Nigerian secondary schools cannot be overemphasized. The Nigerian education system must continue to undergo reforms to be competitive with other developed nations and depart from the system set up by colonial rulers, which was designed to help Nigeria as rightly stated by World Bank Report (2002) that "old education system in many African countries were not developed to empower Africa". This statement simply suggests that there is an urgent need for education reform in Nigeria.

The use of ICTs in the educative process is divided into two broad categories; ICT for education and ICT in education. ICT for education refers to the development of ICTs specifically for teaching and learning purpose, while ICTs in education involves the adoption of a general component of ICTs in the teaching and learning process.Duker (2018) emphasized that ICTs use in school curriculum depends highly on the teacher who will use ICTs to teach the students. This requires that teachers should have the ability to incorporate ICTs into teaching and learning.Alt (2018) noted that the application of ICTs to teaching and learning makes instruction more interesting, effective and productive. Looking at the role of education in nation building and admission explosion in the secondary schools these days, the use of ICT in a teaching-learning process becomes imperative. This is true because its adoption by the teachers would enhance effective teaching such as good course organization,effective classroom management, content creation, self-assessment, self-steady collaborative learning and task-oriented activities. Effective communication between the actors of teaching and research activities would be enhanced by the use of ICT based technology. This study 
analyzed ICT facilities availability and usage in teaching Physics in Science Secondary Schools in Kano state.

\section{StAtement OF PRoblem}

The use of ICT in Secondary School education seems to be lagging behind expectation and desire. This was same that most Secondary Schools in Kano state have computer equipment but only a fraction are with basic ICT resources such as Computers, Internet Connectivity, Multimedia Projectors, Interactive Radio, Teleconferencing, Audio Tape, Printers, Photocopiers, Fax Machines, Dictating Machine etc. that are necessary for teaching and learning. Lack of literate teachers and irregular power supply appear to thrive in the schools and lack of fund to schools. Essentially, ICT in education is used to promote information literacy, which is the ability to access, use, evaluate information from different sources to enhance teaching and learning, solve problems and generate new knowledge. United Nation and World Bank affirm that ICTs can increase access to education network for students, teachers, and broaden the availability of quality education material in Physics (Hu, Bhanu and Prateek, 2019). Therefore, the researchers intended to analyse Information and Communication Technology (ICT) facilities availability and usage in teaching Physics in Science Secondary Schools in Kano state.

\section{The objective of the Study}

The study analyzed Information and Communication Technology (ICTs) facilities availability and usage in Science Secondary Schools in Kano state. Specifically, the study was to:

1) Find out ICT resources availability to Physics Teachers in Science Secondary Schools in Kano state.

2) Find out whether ICT resources are used in the teaching of Physics by Physics teachers in Science Secondary Schools in Kano state.

\section{Research Questions}

The following research questions were posed to guide the study:

1) What is the extent of availability of ICT resources to Physics Teachers in the teaching of Physics in Science Secondary Schools, Kano state?

2) What is the extent of usage of ICT resources in the teaching of Physics by Physics Teachers in Science Secondary Schools, Kano state?

\section{METHODOLOGY}

\section{Population and Sample size}

Descriptive survey design was used for this study.. The population for the study consisted of all Physics teachers drawn from Science Secondary Schools, Kano State, Nigeria. Since the population is sizeable, there was no sampling.

\section{Instrument}

The Questionnaire was divided into three sections A, B and C. Section A consists of personal information of the respondents such as gender, age, working experience and teaching qualification.Section B consists of 10 items in ICT resources availability in Science Secondary (ICTRASS) and finally section $\mathrm{C}$, consists of 10 items which sought information on the Physics teachers' awareness on ICT resources usage in Science Schools (ICTRUSS) in Kano state of Nigeria. Five point Likert Scale was used as follows: Strongly Agree (S.A - 5), Agree (A - 4), Neutral (N - 3), Disagree (D - 2) and Strongly Disagree (S.D - 1).

Validity

Three experts validated the Information and Communication Technology Facilities Availability in Science Secondary (ICTFASS) and Information and Communication Technology Resources Usage in Science Secondary (ICTFUSS). Two Ph.D holders from Mathematical Sciences Education Department, National Mathematical Center, Abuja and one Ph.D holder from Information and Communication Technology Department,Bayero University, Kano assessed both the face and content validity of the instruments.

\section{Reliability}

A pilot study was conducted with sampled schools not involved in the study. The pilot study sample of 15 Physics teachers in secondary schools not under Science and Technical Schools Board, Kano state was used for both instruments. The reliability coefficient was computed using Cronbach alpha (alpha coefficient) formula and found to be 0.80 for ICTFASS and 0.75 for ICTFUSS. The instruments are therefore reliable and were used for data collection in this study.

\section{Procedure}

The researchers collected data through the administration of the questionnaires (ICTFASS \&ICTFUSS) from the Physics teachers of science schools, Kano state. The collection of data was done through personal administration and with the aid of staff in Science and Technical Schools Board (STSB) Kano state, as research assistants in the respective schools. The researchers used one month for administering and collecting the data from the schools. Out of forty copies of the questionnaire distributed only thirty-two copies were returned;representing $80 \%$, while eight copies were not returned, representing $20 \%$.

\section{RESULT}

The purpose of this study was to investigate the analysis of availability and usage of information and communication technology (ICTs) resources in science secondary schools,Kano state. The purpose of the study was achieved by asking Physics teachers to rate their schools on the issue of availability and usage of information and communication technology resources in their schools by using a 5 point Likert scale. The scores of teachers' responses were analyzed using the SPSS version 19.0 software-computing program to compute descriptive statististics.

\section{Research Question 1}

What is the extent of availability of ICT resources to Physics Teachers in the teaching of Physics in Science Secondary Schools, Kano state? 
Table 1: Mean and Standard Deviation Scores of Responses of Physics Teachers on Availability of Information and Communication Technology (ICTs) Resources in Science Secondary Schools in Kano State

\begin{tabular}{lllll}
\hline S/N & ICT Resources & Mean & Std Deviation & Decision \\
\hline 1 & There is a computer set & 3.5313 & 0.5070 & Agree \\
2 & Internet & 2.1875 & 0.6927 & Disagree \\
3 & Radio & 2.3438 & 0.7874 & Disagree \\
4 & Projector & 2.2500 & 0.7184 & Disagree \\
5 & Television & 2.8438 & 0.7233 & Disagree \\
6 & Slides & 2.0625 & 0.6189 & Disagree \\
7 & Video & 2.0937 & 0.7344 & Disagree \\
8 & Disc Player & 2.3438 & 0.7874 & Disagree \\
9 & Bulletin Board & 2.9375 & 0.7156 & Disagree \\
10 & Smart/White Board & 3.1250 & 0.7513 & Agree \\
\hline
\end{tabular}

Grand mean $=2.5719$

Table 1 above has an overall cumulative mean of 2.5719 but a decision mean value is 3.000. Values below and above are considered inadequate and available respectively. While values within the average are considered inadequate (Solar-Gazagnes, Faucher,Jacqueminet,Duboise-Laferge, Mosnier, Roussel and Larder 2019).It could be seen from the table according to teachers that ICT resources that are readily available include Computer set (Mean 3.5313 and SD 0.5070), Smart/Whiteboard (Mean 3.1250 and SD 0.7513), Bulletin Board (Mean 2.9375 and 0.7156), and Television (Mean 2.84338 and SD 0.7233) in Science Secondary

Schools in Kano state. In other hands, ICT Resources such as

Table 2: Mean and Standard Deviation Scores of Responses of Physics Teachers on Usage of Information and Communication Technology (ICTs) Resources in Science Secondary Schools in Kano State.

\begin{tabular}{|c|c|c|c|c|}
\hline $\mathrm{S} / \mathrm{N}$ & Items & Mean & Std Deviation & Decition \\
\hline 1 & $\begin{array}{l}\text { There are functional internet connections owned by the } \\
\text { school for browsing }\end{array}$ & 2.0000 & 0.7620 & Disagree \\
\hline 2 & Physics teachers have access to ICT resources for teaching & 2.0313 & 0.7399 & Disagree \\
\hline 3 & There are enough ICT resources to teach students & 2.1875 & 0.6445 & Disagree \\
\hline 4 & $\begin{array}{l}\text { Physics teachers are knowledgeable in the use of ICT } \\
\text { resources }\end{array}$ & 2.2812 & 0.6832 & Disagree \\
\hline 5 & $\begin{array}{l}\text { Periodic training is organized for physics teachers in the use } \\
\text { of ICT resources }\end{array}$ & 2.0313 & 0.5379 & Disagree \\
\hline 6 & I use a photocopier machine, scanner and printer & 3.0000 & 0.7620 & Agree \\
\hline 7 & I use smart/white board in teaching physics & 3.2500 & 0.5080 & Agree \\
\hline 8 & I use PowerPoint as a teaching tool in physics lessons & 2.0313 & 0.6488 & Disagree \\
\hline 9 & $\begin{array}{l}\text { I use a computer system for research or teaching in physics } \\
\text { lessons }\end{array}$ & 2.4375 & 0.7156 & Disagree \\
\hline 10 & I use video in teaching physics & 1.9375 & 0.7156 & Disagree \\
\hline
\end{tabular}

Table 2 above shows that Photocopier machine, Scanner, Printer, Smart/White board are being used considerably by the Physics Teachers in science secondary schools in Kano state. On the other hand, the use of functional internet facilities owned by schools, ICT resources, technical know-how of ICT resources are very rare by physics teachers in science secondary schools in Kano state. The use of video in teaching physics is reported to be absent completely in virtually all of the Science Secondary Schools in Kano state.

\section{DISCUSSION}

This study investigated the Analysis of Availability and Usage of Information and Communication Technology (ICT) Facilities in the Teaching of Physics in Science Secondary
Radio (Mean 2.3438 and SD 0.7874), Projector (Mean 2.2500 and SD 0.7184), Internet (Mean 2.1875 and SD 0.6927), Disc player (Mean2.3438 and SD 0.7874) are rarely available in the Science Secondary Schools in Kano. While Slides (Mean 2.0625 and SD 0.6189), Video (Mean2.0937 and SD 0.7344) are reported to be absent completely in Science Secondary Schools in Kano state.

\section{Research Question 2}

What is the extent of usage of ICT resources in the teaching of Physics by Physics Teachers in Science Secondary Schools, Kano state?
Schools in Kano State. The research questions answered were :

\section{Research Question 1}

What is the extent of availability of ICT resources to Physics Teachers in the teaching of Physics in Science Secondary Schools, Kano state?

The finding is in conformity with that of Livingstone (2015) which revealed that the school management and stakeholders should endeavour to provide more ICT resources especially the internet, digital and video cameras, which are equally important. The finding of Lawrence (2016) also revealed that ICT resources are not available in most of the senior secondary schools and that most chemistry teachers do not utilize even the few available ICT resources in teaching. In 
addition, the result of Utibe-Abasi (2016) shows that most of the physics teachers in Akwa Ibom are aware of ICT resources such as computer sets, television sets, video sets and audio tape players. In addition, most of the schools were not connected to the internet and hence physics teachers have no access to the internet for use in physics curriculum delivery and most of the physics teachers are not computer literate.

\section{Research Question 2}

What is the extent of usage of ICTs resources in the teaching of Physics by Physics Teachers in Science Secondary Schools, Kano state?

The finding from table 2 shows that the few available ICT resources are underutilized. This is in agreement with the findings of Onosanya, Shehu, Ogunlade and Adefuye (2011). Ndirika and Kanu (2012) who separately reported that the extent of Science Teachers' utilization of ICT resources is low in Oyo and Abia. This finding also is in line with that of Livingstone (2015) who revealed that the use of ICT resources in lesson delivery was low due to factors such as inadequate ICT resources and lack of appropriate ICT skills among others.

\section{SUMMARY OF FINDINGS}

This study investigated the analyses of availability and usage of Information and Communication Technology (ICT) resources in the teaching of Physics in Science Secondary Schools in Kano State. The summary of the findings are as follows:

1) The study has revealed that ICT resources are not available in reasonable number in majority of the Science Secondary Schools, in Kano state.

2) The available ICT resources are not utilized properly by Physics Teachers despite the impact of ICT resources in Physics education

\section{CONCLUSION/RECOMMENDATION}

This study investigated the analyses of availability and usage of Information and Communication Technology (ICT) resources in the teaching of Physics in Science Secondary Schools in Kano State. From the findings of the study, it is recommended that:

1) Government and non-governmental organizations should work very hard to assist to supply ICT resources for effective teaching and learning of Physics and provide internet connectivity to all science secondary schools in Kano state.

2) Massive training should be organized from time to time to make Physics teachers effective in the usage of ICT resources and to encourage Physics teachers to utilize the available ICT resources.

\section{REFERENCES}

[1] Alt, D. (2018). "Science teachers' conceptions of teaching and learning, ICT efficacy,

[2] ICT professional development and ICT practices enacted in their classrooms". Teaching and Teacher Education. 73: 141-150.
[3] Duker, J. B., Ebenezer, A. A., Maria, G. D. (2018). "Influence of the internet on the academic achievement of Senior High School students in the Cape Cost Metropolis of Ghana. "International Journals of Scientific Research and Management. 6(08)

[4] Husain, H., (2019). "Development of Analog-Based Online Electronic Learning Models in Improving Students Learning Outcome in Informatics Engineering Study Program".

[5] Hu, X.N., Bhanu, L.S., and Prateek, R.M. (2019). "Steering AI and advance ICTs for knowledge societies: a Rights, Openness, Access, and Multi-stakeholder Perspective, UNESCO Publishing

[6] Karanji, M. (2018). "Role of ICT in dissemination of information in secondary schools in Kenya: A Literature based review. Journal of Information and Technology, 28-38.

[7] Lawrence, A. (2016). "The availability and utilization of some selected Information Technology facilities among senior secondary school chemistry teachers in Kogi state". International Journal of Scientific \& Engineering Research, vol 7. ISSN 2229-5518.

[8] Livingstone, M.J. (2015). "Use of ICT in Teaching Physics: A case of secondary schools in Kimilili District, Bungoma County, Kenya, Kenyatta University

[9] Ndirika, M.C. and Kanu, N.E. (2013). "Availability and utilization of Information and Communication Technology in Umaahia Education Zone Abia state, Nigeria". 53th Annual Conference Preceding of Science Teachers Association of Nigeria, 284- 289.

[10] Onosanya, S.A., Shehu, R.A., Ogunlade, O.O., Adefuye, A.L. (2011) "Teachers awareness and Extent of Utilization of Information and Communication Technology for Effective Science and Health Education in Nigeria". Singapore Journal of Scientific Research, 1, (1), 49-58.

[11] Richmond, W.K. (2018).The teaching revolution, Routledge.

[12] Rumrill, P.D., Cook, B.G., and Stevenson, N.A. (2020). "Research in special education: Design, methods and application", Charles C Thomas Publisher.

[13] Sola-Gazagnes, A.C., Jacqueminet, S.C., Duboise-Lafargue, M.P., and Rousel, L.E (2019). "Disagreement between capillary blood glucose and flash glucose monitoring sensor can lead to inadequate treatment adjustment during pregnancy." Diabetes \& metabolism.

[14] Utibe-Abasi, S.S. (2016). "Availability, Accessibility and Utilization of Information and Communication Technology in Physics Teaching in AkwaIbom state, Nigeria, West Africa". Canadian Centre of Science Education". Vol 7, ISSN 1913-1844, E- ISSN 1913-1852.

[15] World Bank Report (2002). Information and Communication Technology. A World Bank Group Strategy. Worshington D.C, the World Bank Group. 